\title{
Effect of ring shakes on mechanical properties of chestnut wood from a Greek coppice forest
}

\author{
by Konstantinos Kakavas ${ }^{1}$, Marina Chavenetidou² and Dimitris Birbilis ${ }^{1}$
}

\begin{abstract}
Measurements of several mechanical and physical properties were carried out to detect possible variations between ring shaken and non-ring shaken logs or between different areas of wood from the same log (i.e., ring shaken $\log$ ). Mature wood from the ring shake area had lower axial compression and hardness strength compared to mature wood away from ring shakes. Wood from ring shakes area had lower tangential swelling and precisely at the position of the shakes, the wood had a higher coefficient of anisotropy than the surrounding wood. The juvenile wood's density from the ring shaken logs was higher compared to that of mature wood, as well as proportional limit and hardness strength. From comparisons between ring shaken and non-ring shaken log properties, the following results were determined: mature wood from any area (independent of the presence of shakes) of ring shaken logs had lower Modulus of Rupture, proportional limits, modulus of elasticity under static bending, axial compression, toughness, and hardness strength compared to mature wood from non-ring shaken logs. Moreover, lower radial swelling was found for ring shaken logs. The juvenile wood's density from ring shaken logs was higher compared either to mature or to juvenile wood from non-ring shaken logs.
\end{abstract}

Keywords: ring shake, chestnut, wood defects, wood strength, mechanical/physical properties

\section{RÉSUMÉ}

On a effectué différentes mesures des propriétés mécaniques et physiques afin de tenter de trouver des différences entre les billes avec des roulures et celles qui nen avaient pas de même quentre le bois pris à différents endroits sur la même bille (sur une bille avec des roulures). Le bois mature d'une partie affectée par la roulure montrait un niveau résistance axiale à la compression et une dureté inférieures à ceux du bois mature loin des zones de roulure. Le bois des zones roulées présentait un moins grand gonflement tangentiel et, au site de la roulure, le bois avait un plus fort coefficient d'anisotropie que le bois environnant. La densité du bois juvénile des billes roulées avait une densité supérieure à celle du bois mûr et une résistance à la rupture et une dureté proportionnelle. La comparaison des bois provenant de billes roulées et non roulées nous permet d'en arriver aux conclusions suivantes : le bois mûr, peu importe doù il venait (indépendamment de la présence de roulures) sur les billes roulées, avait un module de rupture, des limites proportionnelles délasticité, un module délasticité en flexion statique, une résistance axiale, une résistance et une dureté inférieures à ceux du bois mûr provenant de billes non roulées. De plus, on a observé un gonflement radial moins important chez les bois avec roulures. La densité du bois juvénile des billes avec roulures était plus élevée comparativement à celle du bois mûr ou juvénile venant de billes non roulées.

Mots-clés : roulure, châtaigner, défauts du bois, résistance du bois, propriétés mécaniques et physiques.

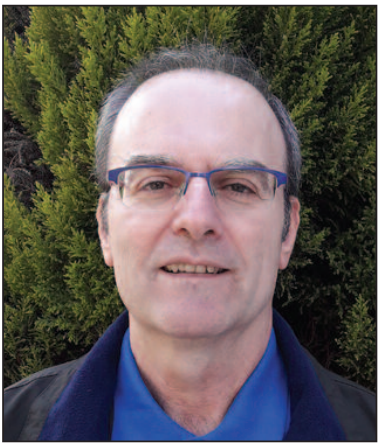

Konstantinos Kakavas

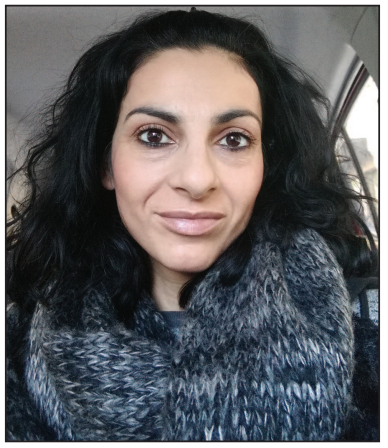

Marina Chavenetidou

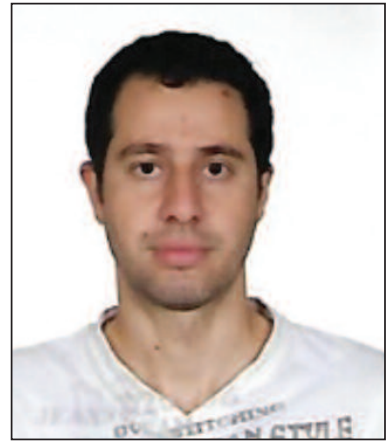

Dimitris Birbilis

\footnotetext{
${ }^{1}$ Technological Educational Institute of Thessaly, Department of Wood and Furniture Design and Technology, Karditsa, Greece; Corresponding author: E-mail kakavas@teilar.gr

${ }^{2}$ Laboratory of Forest Utilization, School of Forestry and Natural Environment, Aristotle University of Thessaloniki, P.O Box 247, 54124, Thessaloniki
} 


\section{Introduction}

Chestnut (Castanea sativa Mill.) is a forest species widespread in the Mediterranean area. Chestnut wood is a valuable raw material in wood manufacturing due to its good mechanical properties, natural durability and attractive appearance. A disadvantage that negatively affects the utilisation of chestnut wood and decreases the timber value is the appearance of ring shakes in logs, a defect occurring as a detachment of wood between growth rings. In certain cases, the appearance of this defect is extensive, causing significant qualitative drop in timber produced (Fonti et al. 2002).

Chestnut trees prone to developing ring shakes after felling may include wood with differentiating mechanical or other properties (Leban 1985; Frascaria et al. 1992; Macchioni 1995; Fonti and Sell 2003; Fonti et al. 2003). These reports contain observations on the basis of which such variations have been identified between ring shaken and non-ring shaken wood. However, it is not clear that this is totally valid, because only some properties, mainly in a radial direction, have been determined and there is not enough evidence for this to be universally accepted. Furthermore, it has not been clarified whether these variations derive from the production of such wood by the tree or are subsequently created due to the existence of ring shake.

Comparing trees of the same age, Spina and Romagnoli (2010) noted that the diameter was not strongly related to the magnitude of defect, but had the effect of moving the ring shake location outwards. Wood defects (star shake, injuries, double core and eccentricity of the core) and stem defects (cortical cancer, epicormic branches, dead branches and bark cracking) were not significantly correlated with shake indeed, only bark cracking and injuries seem to have a slight influence on ring shake risk. Macchioni and Pividori (1996) also found that ring shake is strongly related to genetic aspects - in the same coppice stand they found stumps completely ring shaken and others without any stem affected by the defect.

Romagnoli and Spina (2013) determined that shaken trees had lower mechanical strength and shrinkages than healthy ones, and that the physio-mechanical parameters might be used to predict ring shake occurrence in a specific geographic area. Geographical location strongly affects physio-mechanical properties of chestnut wood, and this factor influences ring shake occurrence. Modulus of Rupture (MOR) values were assumed to be the parameter that could be applied to almost all study sites to distinguish between shaken and healthy trees. There was no difference between the shaken and healthy portions of the disk inside the same tree.

Relationships between ring width, age of wood, physical and mechanical properties, which sometimes may affect ring shake occurrence, have been highlighted by Fioravanti (1995); Adamopulos et al. (2010); Adamopulos et al. (2011) and Romagnoli et al. (2014).

In this paper, measurements of several mechanical and physical properties of wood were determined to detect possible variations between ring shaken and non-ring shaken logs and between different areas on cross sections of ring shaken logs. Up to now, only variations between ring shaken and non-ring shaken wood, mainly in a radial direction, have been examined. By grading the samples not only by different
Table 1. Sample positions on ring-shaken logs

\begin{tabular}{ll}
\hline Code & $\begin{array}{l}\text { Sample position according } \\
\text { to the distance from ring shake }\end{array}$ \\
\hline 0 & Sample precisely on ring shake area \\
1 & Sample next to ring shake \\
2 & Sample at 5 mm distance from ring shake \\
3 & Sample at more than $5 \mathrm{~mm}$ distance from ring shake \\
\hline
\end{tabular}

trees but also at different distances from the ring shaken area, and by examining a greater variety of mechanical properties, more complete information of ring shake defect behavior on mechanical properties may be obtained.

Chestnut juvenile wood was the area of the first 10 rings around the pith based on previous studies (Fioravanti 1995; Militz et al. 2003; Chavenetidou 2009; Adamopulos et al. 2010; Adamopulos et al. 2011), from which we quote: "In chestnut wood, the increase in fibre length is greater up to the age of 10-12 years and then is gradually reduced. This area of change of growth coincides with the transition age from 'immature' (juvenile) to 'typical' wood" (Chavenetidou 2009). With chestnut coppice wood from central Italy, lateral dimensions (radial, tangential) of the vessels at the base and at a height of $5 \mathrm{~m}$ from the trunk increased from the pith to the outer wood (Fioravanti 1995). The increase is greatest initially up to 8-10 years of vessel age. The mean dimensions were larger at the base compared to the corresponding dimensions at a height of $5 \mathrm{~m}$. The ratio of the radial to the tangential dimension decreased from the pith to outer wood at both heights. The decrease was initially also higher up to the age of 8-10 years.

\section{Materials and Methods}

Nine logs ( $2 \mathrm{~m}$ long) were selected from a coppice forest in Halkidiki, Greece, five without ring shakes and four with ring shakes. Logs were sawn to produce $2.5 \mathrm{~cm}$ thick boards and $50 \times 2 \times 2 \mathrm{~cm}$ (axial $\times$ radial $\mathrm{x}$ tangential) samples were cut. The samples from ring-shaken logs were classified according to their distance from ring shakes as described in Table 1 and shown in Fig. 1 and 2.

Mechanical properties were determined according to established international standards using the standardized methods described in detail and contained in those standards (Table 2). The length, width, height, and mass of each specimen were recorded to determine air-dry densities. All specimens were conditioned at $20{ }^{\circ} \mathrm{C}$ and $65 \%$ relative humidity before testing. The mechanical properties of bending and compression were determined on a Shimatdzu strength machine while an Amsler strength machine was used for hardness and toughness.

For MOR (Modulus of Rupture) and MOE (Modulus of Elasticity) measurements, a static bending test was performed using a Shimadzu testing machine by centre point loading over a $30-\mathrm{cm}$ span. Half of the specimens with narrow or wide growth rings were loaded in the radial direction while the other half in the tangential direction. The load applied was about half of the estimated proportional load limit for each specimen and was based on previous tests. The crosshead 


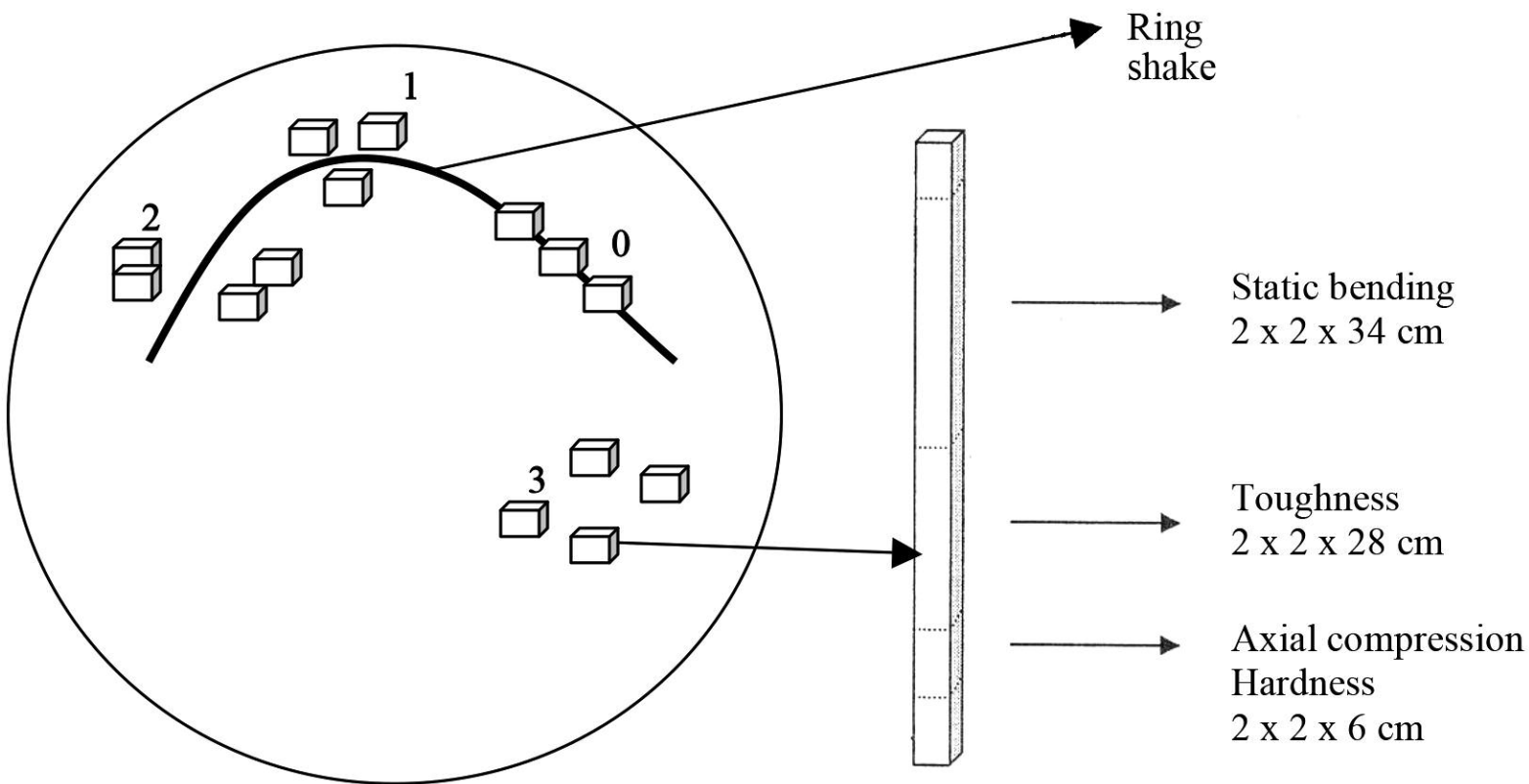

Fig. 1. Sample positions on ring shaken logs. From each sample test specimens were cut to determine mechanical properties.

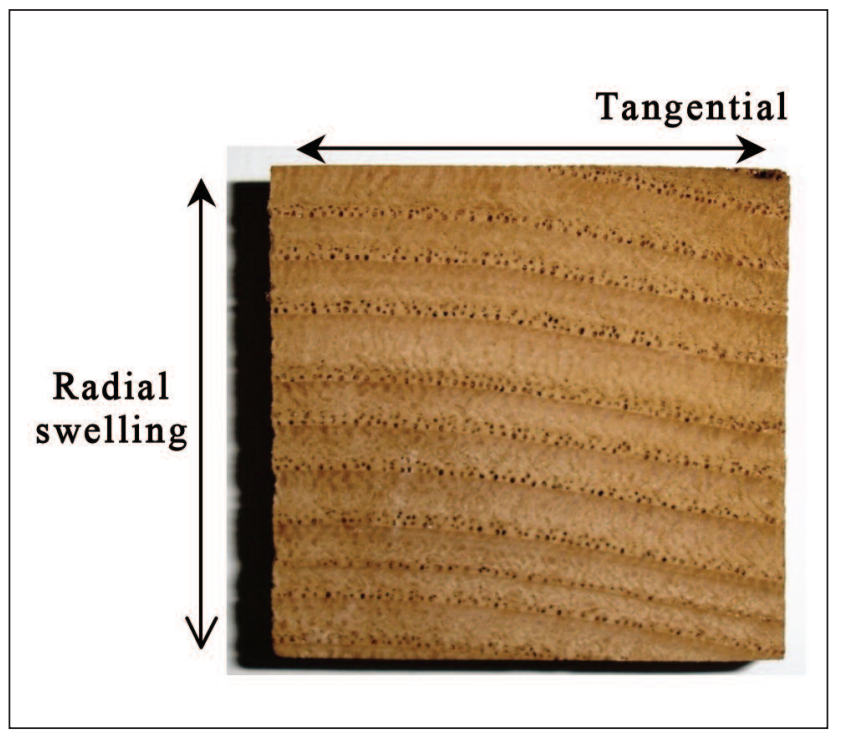

Fig. 3. Sample for radial and tangential swelling measurements

speed (6 $\mathrm{mm} / \mathrm{min})$ was according to DIN $52186: 1978$ (Deutsche Industrie Normen 1988). From the stress strain diagram taken for each specimen, the fracture load (maximum load), the load at the elastic limit as well as the corresponding bending arrow were determined.

This methodology determines the 'experimental modulus of elasticity'. However, a methodology developed and used by Preston (1954), Wangaard (1964), Biblis (1965) and Chow (1972) was used to determine the real modulus of elasticity. With this methodology, it is possible to determine the actual shear modulus or modulus of rigidity at the same time, and is based on the relationship between the previously mentioned properties and the flexural elastic modulus.

From the load deflection curve, the modulus of elasticity (MoE) in radial and tangential planes were obtained as follows:
$\mathrm{MoE}=\mathrm{PL}^{3} / 4 \mathrm{bd}^{3} \mathrm{y}$
Where:
MoE: modulus of elasticity, $\mathrm{N} / \mathrm{mm}^{2}$
$\mathrm{P}$ : load in the region of proportionality, $\mathrm{N}$
$\mathrm{L}$ : length between specimen supports, $\mathrm{mm}$
b: width of specimen, $\mathrm{mm}$
$\mathrm{d}$ : height of specimen, $\mathrm{mm}$
$\mathrm{y}$ : mid span deflection of specimen at load $\mathrm{P}, \mathrm{mm}$

From the samples with code 0 , (precisely on the area of ring shakes), the specimens were cut in a way that ring shake was not present in the final specimen (Fig. 2), following the length of the original bar up to the disappearing ring crack (Fig. 1 and 2).

It should be noted that toughness tests were conducted on an Amsler Universal wood testing machine at $24-\mathrm{cm}$ span with centre loading. For each specimen, the impact of the falling pendulum occurred in the respective plane (radial or tangential) of the static bending test. The impact bending strength was determined according to DIN 52189:1981. It was tested according to the hammer method on specimens with a cross section of $20 \times 20 \mathrm{~mm}$. The energy (Newton) required to break the sample by the swing of the hammer was recorded. The impact bending strength is expressed as $\mathrm{kJ} / \mathrm{m}^{2}$. The work produced from fracturing the specimen was noted and toughness strength was calculated according to DIN 52189:1981 as follows: 
Table 2. Description of mechanical properties test specimens

\begin{tabular}{|c|c|c|c|c|c|}
\hline Test & $\begin{array}{l}\text { Type } \\
\text { of } \\
\text { wood }\end{array}$ & $\begin{array}{c}\text { Non-ring } \\
\text { shaken } \\
\text { logs }\end{array}$ & $\begin{array}{c}\text { Ring } \\
\text { shaken } \\
\text { logs }\end{array}$ & $\begin{array}{c}\text { Dimensions } \\
\text { (rad. } x \text { tang. } \\
\quad x \text { ax. }) \mathrm{cm}\end{array}$ & Standard \\
\hline Static bending & $\begin{array}{l}\text { Mature } \\
\text { Juvenile }\end{array}$ & $\begin{array}{c}125 \\
18\end{array}$ & $\begin{array}{c}106 \\
11\end{array}$ & $2 \times 2 \times 34$ & DIN 52186: 1978 \\
\hline Axial compression & $\begin{array}{l}\text { Mature } \\
\text { Juvenile }\end{array}$ & $\begin{array}{l}75 \\
25\end{array}$ & $\begin{array}{c}129 \\
17\end{array}$ & $2 \times 2 \times 6$ & DIN 52185: 1976 \\
\hline Toughness & $\begin{array}{l}\text { Mature } \\
\text { Juvenile }\end{array}$ & $\begin{array}{l}75 \\
20\end{array}$ & $\begin{array}{c}61 \\
9\end{array}$ & $2 \times 2 \times 28$ & DIN 52189: 1981 \\
\hline Hardness & $\begin{array}{l}\text { Mature } \\
\text { Juvenile }\end{array}$ & $\begin{array}{l}75 \\
20\end{array}$ & $\begin{array}{c}61 \\
9\end{array}$ & $2 \times 2 \times 6$ & BS 373:1957 \\
\hline
\end{tabular}

The determination of hardness was conducted by the Janka method and carried out on the tangential and radial surfaces with a corresponding (tangential and radial) direction of application of the load at a constant speed of $6 \mathrm{~mm} / \mathrm{min}$ (British Standards Institution 1957).

Table 2 shows the number and the dimensions of test specimens used for the determination of mechanical properties. The number of specimens for each class of ring shaken logs according to their distance from ring shakes is shown in Table 3.

Test specimens $(2 \times 2 \times 5 \mathrm{~cm}$; rad. $\mathrm{x}$ tang. $\mathrm{x}$ ax.) were also cut from the chestnut samples (mature wood) to measure radial and tangential swelling (Fig. 3) and

Table 3. Number of specimens from each position of ringshaken logs

\begin{tabular}{lccc}
\hline $\begin{array}{l}\text { Code } \\
\text { (position) }\end{array}$ & $\begin{array}{c}\text { Static } \\
\text { bending }\end{array}$ & $\begin{array}{c}\text { Axial } \\
\text { compression }\end{array}$ & $\begin{array}{c}\text { Toughness / } \\
\text { Hardness }\end{array}$ \\
\hline 0 & 12 & 32 & 15 \\
1 & 14 & 32 & 11 \\
2 & 21 & 17 & 5 \\
3 & 59 & 48 & 30 \\
\hline Total & $\mathbf{1 0 6}$ & $\mathbf{1 2 9}$ & $\mathbf{6 1}$ \\
\hline
\end{tabular}

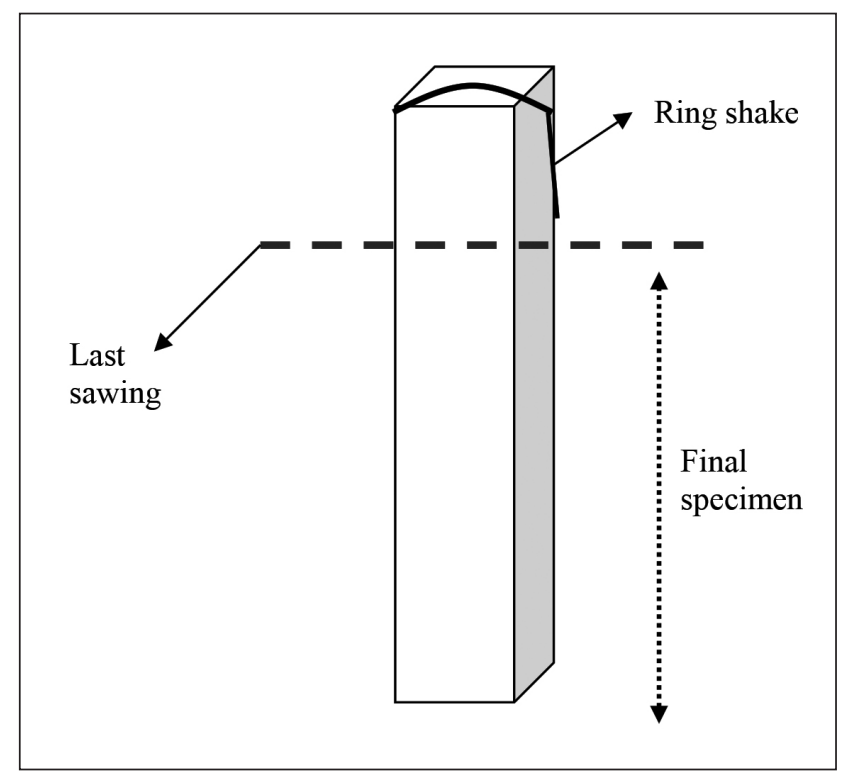

Fig. 2. Final specimens from ring shake area (code 0)

\footnotetext{
$\mathrm{W}=1000 \mathrm{w} / \mathrm{bd}$

Where:

$\mathrm{W}$ : toughness, $\mathrm{kJ} / \mathrm{m}^{2}$

$\mathrm{w}$ : work to total fracture, $\mathrm{J}$

b: width of specimen, $\mathrm{mm}$

$\mathrm{d}$ : height of specimen, $\mathrm{mm}$
}

coefficient of anisotropy, but not axial swelling. These specimens were used for measurements of oven-dry density. Thirty-two specimens were cut from ring shaken logs and 20 cut from non-ring shaken logs. They were dried to $0 \%$ moisture content and then immersed in water up to $>30 \%$ moisture content. For the calculation of maximum swelling, the samples were placed in an oven at $103 \pm 2{ }^{\circ} \mathrm{C}$ for 24 hours, and then their weight and dimensions (in dry state) were measured. They were placed fully covered in water for 72 hours until their dimensions were stabilized, and then re-measured at the level of maximum swelling.

\section{Results and Discussion}

The mean values of mechanical properties and air-dry densities are shown in Table 4 . Table 5 shows the statistically significant differences ( $\mathrm{p}<0.05$ for confidence limit $95 \%$ ) between the areas that were revealed from ANOVA (Analysis of Variance).

From the test on static bending, the Modulus of Rupture $(\mathrm{MoR})$, proportional limit (PL) and modulus of elasticity (MoE) were determined according to DIN 52186:1978. All values were higher (statistically significant, $\mathrm{p}<0.05$ for confidence limit $95 \%$ ) for the non-ring-shaken logs. In ring shaken logs, wood from the shaken area (code 0 ) had a lower proportional limit compared to wood from other positions (code 1,2,3) of the same ring shaken log. Juvenile wood from ring shaken logs had higher proportional limits compared to mature wood from the same logs (Tables 4 and 5).

The test on axial compression (DIN 52185:1976; Deutsche Industrie Normen 1988) revealed higher strengths for nonring shaken logs compared to ring shaken logs, and lower strength of areas close to the ring shake (code 0,1$)$ compared to areas at a distance from the ring shake (code 2,3) from the same ring shaken $\log$ (Tables 4 and 5).

From the test on toughness (DIN 52189:1981; Deutsche Industrie Norment 1988), the non-ring shaken logs had greater strength compared to ring shaken logs (Tables 4 and 5).

The test on hardness (British Standards Institute 1957) revealed greater strength for non-ring shaken logs compared to ring shaken logs, and lower strength of areas close to the ring shake (code 0,1$)$ compared to areas at a distance from ring shake (code 2,3 ). Juvenile wood from ring shaken logs had higher hardness compared to mature wood from the same logs (Tables 4 and 5). 
Table 4. Mean values of mechanical properties and air-dry density

\begin{tabular}{|c|c|c|c|c|c|c|c|}
\hline \multirow[b]{3}{*}{ Property $^{*}$} & \multicolumn{5}{|c|}{ Logs with ring shakes } & \multicolumn{2}{|c|}{ Logs without ring shakes } \\
\hline & \multirow[b]{2}{*}{ Juvenile } & \multicolumn{4}{|c|}{$\begin{array}{c}\text { Mature } \\
\text { (code as defined in table } 1 \text { and figure } 1 \text { ) }\end{array}$} & \multirow[b]{2}{*}{ Juvenile } & \multirow[b]{2}{*}{ Mature } \\
\hline & & $\mathbf{0}$ & 1 & 2 & 3 & & \\
\hline \multicolumn{8}{|l|}{ Static bending } \\
\hline $\operatorname{MoR}\left(\mathrm{N} / \mathrm{mm}^{2}\right)$ & 101.47 & 97.84 & 93.86 & 97.56 & 96.79 & 108.40 & 107.71 \\
\hline Proportional limit $\left(\mathrm{N} / \mathrm{mm}^{2}\right)$ & 48.70 & 42.82 & 44.66 & 44.00 & 43.88 & 47.76 & 46.20 \\
\hline MoE, Tangential $\left(\mathrm{kN} / \mathrm{mm}^{2}\right)$ & 16.99 & 14.67 & 15.42 & 16.52 & 15.95 & 18.96 & 19.00 \\
\hline MoE, Radial $\left(\mathrm{kN} / \mathrm{mm}^{2}\right)$ & 16.05 & 14.37 & 14.12 & 15.59 & 15.14 & 18.00 & 17.01 \\
\hline Axial compression $\left(\mathrm{N} / \mathrm{mm}^{2}\right)$ & 58.59 & 53.31 & 51.54 & 57.66 & 58.15 & 60.81 & 60.32 \\
\hline Toughness (Joule/cm²) & 3.95 & 3.96 & 3.65 & 4.72 & 4.26 & 4.59 & 5.18 \\
\hline \multicolumn{8}{|l|}{ Hardness $\left(\mathrm{N} / \mathrm{mm}^{2}\right)$} \\
\hline tangential & 42.85 & 36.64 & 33.54 & 39.20 & 40.28 & 43.07 & 41.07 \\
\hline radial & 43.77 & 33.08 & 32.30 & 36.95 & 37.65 & 42.45 & 40.29 \\
\hline Air-dry density $\left(\mathrm{g} / \mathrm{cm}^{3}\right)$ & 0.655 & 0.616 & 0.599 & 0.626 & 0.624 & 0.615 & 0.629 \\
\hline
\end{tabular}

${ }^{*}$ Radial or tangential according to the load direction.

Table 5. p-values from mechanical property comparisons with statistically significant differences

\begin{tabular}{|c|c|c|c|c|}
\hline Mechanical properties & $\begin{array}{l}\text { Logs with } \\
\text { ring shakes }\end{array}$ & $\begin{array}{l}\text { Logs without } \\
\text { ring shakes }\end{array}$ & $\begin{array}{l}\text { Wood areas } \\
\text { far from } \\
\text { ring shakes } \\
(\text { code } 2,3)\end{array}$ & $\begin{array}{l}\text { Wood areas } \\
\text { close to } \\
\text { ring shakes } \\
(\text { code } 0,1)\end{array}$ \\
\hline MOR & & & & \\
\hline MOR & & & & \\
\hline MOE (tang) & & & & \\
\hline Axial compression & & & & \\
\hline MOE (rad) & & & & \\
\hline MOE (tang) & & & & \\
\hline Toughness & & & & \\
\hline Hardness (rad) & & & & \\
\hline MOE (rad) & & & & \\
\hline Axial compression & & & \multicolumn{2}{|c|}{0.00008} \\
\hline PL & & & & \\
\hline Toughness & & & & \\
\hline PL & & & & \\
\hline Hardness (rad) & & & \multicolumn{2}{|c|}{0.01} \\
\hline Hardness (tang) & & & & \\
\hline Hardness (rad) & & & \multirow{2}{*}{\multicolumn{2}{|c|}{0.022}} \\
\hline Hardness (tang) & & & & \\
\hline Axial compression & & & & \\
\hline
\end{tabular}

Air-dry density of the juvenile wood specimens from ring shaken logs was higher compared to other types of wood (mature from ring shaken logs, juvenile and mature from non-ring shaken logs; Table 4). Juvenile wood in chestnut has usually higher property values than mature wood (Fioravanti 1995; Adamopulos et al. 2010; Adamopulos et al. 2011). Due to the distribution of stress inside the tree, ring shake is rarely present in juvenile wood (Fonti et al. 2003; Romagnoli and Spina 2013; Romagnoli et al. 2014).

Mature wood from any area (independent of the presence of shake) of ring shaken logs had lower mechanical strength compared to mature wood from non-ring shaken logs (Table 
Table 6. Mean values of the swelling properties and oven-dry density

\begin{tabular}{lccccc}
\hline $\begin{array}{l}\text { Code (for ring } \\
\text { shaken logs) }\end{array}$ & $\mathbf{n}$ & $\begin{array}{c}\text { Radial } \\
\text { swelling }\end{array}$ & $\begin{array}{c}\text { Tangential } \\
\text { swelling }\end{array}$ & $\begin{array}{c}\text { Coefficient } \\
\text { of anisotropy }\end{array}$ & $\begin{array}{c}\text { Oven-dry } \\
\text { density } \mathbf{g} / \mathbf{c m}^{3}\end{array}$ \\
\hline 0 & 8 & $3.55 \%$ & $7.36 \%$ & 2.09 & 0.555 \\
1 & 8 & $3.34 \%$ & $8.08 \%$ & 2.43 & 0.538 \\
2 & 8 & $4.32 \%$ & $8.80 \%$ & 2.16 & 0.600 \\
3 & 8 & $4.00 \%$ & $9.24 \%$ & 2.37 & 0.585 \\
Ring shaken logs & 32 & $3.80 \%$ & $8.37 \%$ & 2.26 & 0.570 \\
Non-ring shaken logs & 20 & $4.69 \%$ & $8.90 \%$ & 1.95 & 0.573 \\
\hline
\end{tabular}

wood) and variations to the extent that vessel members and rays occupy in transverse sections of mature chestnut wood. In agreement with Fonti et al. (2003) and other research, we suggest an expanded hypothesis be investigated, i.e., that in chestnut trees, wood characteristics will likely differentiate (as a form of reaction, similar to reaction wood) when these trees receive excessive stress, either from internal (growth stresses) or external factors that cause ring shake.
5). The wood areas at a distance (code 2, 3) from ring shake but belonging to ring shaken logs had lower values compared to wood from non-ring shaken logs.

Table 6 shows the mean values of the swelling properties and oven-dry density from mature wood. Statistically significant differences ( $p<0.05$ for confidence limit $95 \%$ ) were determined for the following:

Wood from ring shaken area (code 0,1$)$ had lower tangential swelling compared to wood further from ring shakes (code 2,3 ) and, precisely at the shakes' position (code 0 ), wood had higher coefficiencies of anisotropy (the property of being directionally dependent) than the surrounding wood (code 1).

Ring shaken logs had lower radial swelling compared to non-ring shaken logs.

From the proceeding, some obvious trends may be observed. For example, some lower mechanical properties and shrinkage almost differentiate ring shaken wood, and are noted in the literature (Leban 1985; Frascaria et al. 1992; Macchioni 1995; Fonti and Sell 2003; Fonti et al. 2003; Romagnoli and Spina 2013). The MoR value, considered a critical parameter, was assumed to be the parameter that could be applied at almost all study sites to distinguish between shaken and healthy trees (Romagnoli and Spina 2013). It is also remarkable that in this research the greatest differences were not between the shaken and healthy portions within the same tree, similar to the findings of Romagnoli and Spina (2013). Some remarkable differences were also found between the shaken and healthy portions within the same tree, and this was due to sampling. Ring shake may run along the log for some centimeters to several metres, and therefore a lower value compared to specimens further from ring shakes (2-3) may be expected.

Reduced mechanical radial resistance of ring shaken wood is reported by other researchers who measured mechanical resistance to static bending and tensile strength in radially oriented specimens from ring shaken and non-ring shaken logs (Leban 1985; Frascaria et al.; 1992, Macchioni 1995). This reduced mechanical strength was associated with structural variations and the development of mechanical stresses that affect the properties of ring-shaken wood (Fonti 2001; Fonti and Frey 2002; Fonti 2003; Fonti et al. 2003).

Combining all the previous results with the results of this research, the hypothesis formulated by Fonti et al. (2003) that wood formation with different characteristics and properties may occur in ring shaken logs is strengthened. This hypothesis was based on results of previous work (Leban 1985; Frascaria et al.; 1992; Macchioni 1995; Fonti 2001; Fonti and Frey 2002) which concerned differences in two mechanical properties (bending and tensile strength in radial strips of chestnut

\section{Conclusions}

Mature wood from the ring shake areas had lower axial compression and hardness strength compared with mature wood further away from ring shakes. Wood from ring shake areas had lower tangential swelling and, precisely at the position closest to the ring shake, had a higher coefficient of anisotropy than the surrounding wood. Juvenile wood density from ring shaken logs was higher compared to mature wood, as well as proportional limit and hardness strength. Comparisons between ring shaken and non-ring shaken logs indicate that mature wood from any area (independently of the presence of shakes) of ring shaken logs had lower Modulus of Rupture, proportional limit, modulus of elasticity under static bending, axial compression, toughness, and hardness strength compared with similar wood from non-ring shaken logs. Lower radial swelling was also found with ring shaken logs. Juvenile wood density from ring shaken logs was higher compared to either mature or juvenile wood from non-ring shaken logs. It also had higher modulus of elasticity under shearing compared to juvenile wood from non-ring shaken logs.

\section{References:}

Adamopoulos, S., M. Chavenetidou, C. Passialis and E. Voulgaridis 2010. Effect of cambium age and ring width on density and fiber length of black locust and chestnut wood. Wood Res. 55: 25-36.

Adamopulos, S., A. Karageorgos, C. Passialis and M. Chavenetidou 2011. Mathematical approach for defining juvenile-mature wood transition zone in black locust and chestnut. Wood Fiber Sci. 43(3): 336-342.

Biblis, E.J. 1965. Analysis of wood-fiberglass composite beams within and beyond the elastic region. Forest Prod. J. 15(2): 81-88.

British Standards Institution 1957. Methods of Testing Small Clear Specimens of Timber. B.S. 373:1957.

Chavenetidou, M. 2009. Anatomical characteristics and technical properties in relation to utilization of chestnut wood (Castanea sativa Mill.) from coppice forests. PhD Thesis, Thessaloniki, AUTh. Chow, P. 1972. Modulus of elasticity and shear deflection of walnutveneered particleboard composite beames in flexure. Forest Prod. J. 22(11): 33-38.

Deutsche Industrie Normen 1988. Prufung von Holz, Bestimmung der Druckfestigkeit parallel zur Faser, DIN 52185:1976.

Deutsche Industrie Normen 1988. Prufung von Holz, Biegeversuch, DIN 52186:1978.

Deutsche Industrie Normen 1988. Prufung von Holz, Schlagbiegeversuch, DIN 52189:1981.

Fioravanti, M. 1995. Nature and occurence of juvenile wood in chestnut (Castanea sativa Mill.) stems from Coppice Forest. Forêt Méditerranéenne 16: 58-66.

Fonti, P. 2001. Do ring-shaken chestnut trees display larger earlywood vessels and/or less radial rays than unshaken ones? Poster 217 in Conference "Tree Rings and People", September 22-26 2001, Davos, Switzerland. 
Fonti, P. 2003. Growth strain and ring shake in chestnut coppices trees. Forêt méditerranéenne 24(2):141-147.

Fonti, P. and B. Frey 2002. Is ray volume a possible factor influencing ring shake occurrence in chestnut wood? Trees: Structure and Function 16(8): 519-522.

Fonti, P. and J. Sell 2003. Radial split resistance of chestnut earlywood and its relation to ring width. Wood Fiber Sci. 35(2): 201-208.

Fonti, P., N. Macchioni and B. Thibaut 2002. Ring shake in chestnut (Castanea sativa Mill.): State of the art. Ann. For. Sci. Vol. 59 (2) $129-140$.

Fonti, P., N. Macchioni, B. Thibaut and J. Sell 2003. Biomechanical adaptation of the wood structure of European chestnut to growth stresses. In: F. Telewski \& F. Ewers (eds.), Proceedings of the 4th International Plant Biomechanics Conference, East Lansing, USA 20 - 25 July 2003.

Frascaria, N., B. Chanson, B. Thibaut and M. Lefranc 1992. Génotypes et résistance mécanique radiale du bois de châtaignier (Castanea sativa Mill.): Analyse d'un des facteurs explicatifs de la roulure, Ann. Sci. For. 49: 49-62.

Leban, J.M. 1985. Contribution à létude de la roulure de châtaignier. Thèse de doctorat, I.N.P.L., Nancy, 164 p.

Macchioni, N. 1995. Mechanical strength and ring shake in chestnut (Castanea sativa Mill.). Forêt Méditerranéenne 16: 67-73.
Macchioni, N. and M. Pividori 1996. Ring shake and structural characteristics of a chestnut (Castanea sativa Mill.) coppice stand in northern Piedmont (northwest Italy). Annales des Sciences Forestières 53: 31-50.

Militz, H., Busetto, D. and F. Hapla 2003. Investigation on natural durability and sorption properties of Italian Chestnut (Castanea sativa Mill.) from coppice stands. Holz Roh-Werkstoff 61:133-141.

Preston, S.B. 1954. The effect of synthetic resin adhesives on the strength and physical properties of wood veneer laminates. Yale University, School of Forestry Bul. No. 60. New Haven, Connecticut.

Romagnoli, M. and S. Spina 2013. Physical and mechanical wood properties of ring-shaken chestnut (Castanea sativa) trees. Can. J. Forest Res. 43(2): 200-207.

Romagnoli, M., D. Cavalli and S. Spina 2014. Wood Quality of Chestnut: Relationship between Ring Width, Specific Gravity, and Physical and Mechanical Properties. Bioresources 9(1): 1132-1147. Spina, S. and M. Romagnoli 2010. Characterization of ring shake defect in chestnut wood in the Lazio Region (Italy). Forestry 83: 315-327.

Wangaard, F.F. 1964. Elastic Deflection of wood-fiberglass composite beams. Forest Prod. J. 14(6): 256-260. 